\title{
Cytoprotectant and Anti-Oxidant Effects of Olive Oil on Cadmium Induced Nephrotoxicity in Mice
}

\author{
Farooq Ahmed Wani ${ }^{1}$, Mahrous AbdelBasset Ibrahim ${ }^{2,3}$, Medhat M. Abdel Moneim ${ }^{4}$, \\ Abdul Rahman Hamdan A. Almaeen 5 \\ ${ }^{1}$ Pathology Department, Faculty of Medicine, College of Medicine, Aljouf University, Aljouf, KSA \\ ${ }^{2}$ Forensic Medicine and Clinical Toxicology Department, College of Medicine, Aljouf University, Aljouf, KSA \\ ${ }^{3}$ Faculty of Medicine, Suez Canal University, Ismailia, Egypt \\ ${ }^{4}$ Department of Medical Biochemistry \& Molecular Biology, Faculty of Medicine, Benha University, Benha, Egypt \\ ${ }^{5}$ Department of Pathology, College of Medicine, Aljouf University, Aljouf, KSA \\ Email: ^farooqafroza@gmail.com, ^fawani@ju.edu.sa, Mahrous_11@yahoo.com, medhatmonim10@yahoo.com, \\ ahalmaeen@ju.edu.sa
}

How to cite this paper: Wani, F.A., Ibrahim, M.A., Moneim, M.M.A. and Almaeen, A.R.H.A. (2018) Cytoprotectant and Anti-Oxidant Effects of Olive Oil on Cadmium Induced Nephrotoxicity in Mice. Open Journal of Pathology, 8, 31-46.

https://doi.org/10.4236/ojpathology.2018.8 1004

Received: December 22, 2017

Accepted: January 8, 2018

Published: January 11, 2018

Copyright (C) 2018 by authors and Scientific Research Publishing Inc. This work is licensed under the Creative Commons Attribution International License (CC BY 4.0).

http://creativecommons.org/licenses/by/4.0/

\section{(c) (i) Open Access}

\begin{abstract}
Background: Cadmium is a heavy metal having toxic effects on most organ systems of the body. Objectives. We aim to investigate the postulated protective properties of olive oil in Cadmium-induced renal toxicity in mice by utilizing standard biomarkers of renal toxicity, oxidative stress and histopathological characterization. Materials and Methods. Forty mice were randomly divided into four groups of 10 mice each. Group 1 served as control group, group 2 was given Extra-virgin olive oil orally, group 3 was given Cadmium chloride and group 4 was given Cadmium chloride with Extra-virgin olive oil. At the end of the experimental period, biochemical analysis histopathology of kidney was done. Results: The present study depicted that blood urea, serum creatinine and the antioxidant markers (Superoxide dismutase, Glutathione peroxidase and Catalase) levels were significantly increased in group 3 compared to group 1 and 2. After administration of Extra-virgin olive oil with Cadmium in group 4, the levels of those markers significantly improved. Histopathology of the renal tissue showed severe damage of glomeruli, severely congested blood vessels and marked dilatation of Bowman's capsule in group 3 with improvements of these changes in group 4. Conclusion: This study suggests that Extra-virgin olive oil can be used as a cost effective safe anti-oxidative agent in the prevention of Cadmium toxicity.
\end{abstract}

\section{Keywords}

Reactive Oxygen Species, Cadmium, EVOO, Nephrotoxicity, Oxidative Stress 


\section{Introduction}

Cadmium (Cd) is a heavy metal having toxic effects on most organ systems of the body [1]. In fact, this environmental pollutant is ranked among the top toxic substances [2]. Human exposure to cadmium occurs through metal industries, contaminated food, air pollution and cigarette smoking [3] [4] [5].

In 1817, it was first proposed by Friedrich Stromeyer (Göttingen, Germany) that cadmium intoxication can cause damage to kidney, bone, and lungs [6]. Accumulation of cadmium occurs mainly in the kidney leading to nephrotoxicity. Cadmium circulates in the blood either in the free form or bound to various carrier proteins such as albumin, glutathione and metallothioneins (MTs) [7]. Free form of cadmium causes the formation of reactive oxygen species (ROS) in the renal cells and induces apoptosis [8]. Renal toxicity primarily damages the initial parts of the proximal tubules especially the S1 and S2 segments [9] [10]. Damage to the proximal tubules results in glucosuria, proteinuria and aminoaciduria.

After filtration from the glomerulus, free form is transported by zinc transporter and divalent cation transporter 1 (DCT1) [11] [12] [13] [14]. Some of the free form is taken care of by other cation transporters like that for calcium and ferrous ions [15]. The bound forms of cadmium utilize the receptor-mediated endocytosis pathway [16] and amino acid transporters [17] for moving across the apical membrane. Zalups proposed that the principal pathway for cadmium entrance into the renal tubular cells may be through the organic cation transporters (OCTs) in the basolateral membrane tubular cells [13].

The cytotoxicity of cadmium results largely from its free form as has been evidenced in many in vitro studies [18] [19] [20] [21]. Quamme [22] in his study showed that in the renal MDCK epithelial cells, the free cadmium is transported into the intracellular space across the membranes, which support the probability of accessibility of CdZ+ for the intracellular milieu and the ability to react with sensitive sites in the renal tissues. Furthermore, Goyer and his co-workers [23] demonstrated in their study that nephrotoxicity might be induced by divalent CdZr, and that basolateral $\mathrm{Cd}$ uptake may significantly contribute to the total renal burden of $\mathrm{Cd}$ under certain conditions [24].

In the diet of Mediterranean area, Olive oil is considered the fundamental source of dietary fat, and different useful effects on the human body health are resulted from its steady consumption [25]. Extra virgin olive oil is well recognized for its antioxidant properties, hypotensive, hypoglycaemic, cardiovascular and hepatoprotective effects [26]. It is also known for its anti-microbial and anti-inflammatory properties [27]. The monounsaturated fatty acids (MUFA) especially oleic acid, which constitutes $70 \%$ - $80 \%$ of total fatty acids, may be instrumental in the favourable effects of olive oil on the cardiovascular system [28]. Phenols present in the olive oil are potent antioxidants and scavenge free radicals and inhibit low-density lipoprotein (LDL) oxidation [29]. Olive oil contains a wide variety of antioxidants such as vitamin E, oleocanthal, carotenoids and especially oleuropein which pre- 
vents the oxidation of LDL particles [30].

One of the studies done by Mohammed et al. (2014) concluded that administration of virgin olive oils and nigella sativa improved the abnormalities in the oxidative antioxidant parameters and the altered biochemical markers and ameliorated organ damage caused by cadmium toxicity in rats [31]. Amamou et al. (2015) in their study found the protective effect of Olive oil or colocynth oil consumption on the rat liver against Cadmium-induced injury and attributed the effects due to the reduced oxidative stress and the enhancements of antioxidant enzymes activities [32].

The experimental demonstration of the protective activities of olive oil against cadmium-induced nephrotoxicity is lacking. This study aims to investigate the postulated protective properties of olive oil in Cadmium-induced renal toxicity in mice by utilizing standard biomarkers of renal toxicity, oxidative stress and histopathological characterization.

\section{Materials and Methods}

\subsection{Mice}

We used Male Swiss albino mice, of almost the same age ( 2 weeks) and weight (20 - $30 \mathrm{gm})$ in our experiment. The mice were housed in plastic cages, fed a standard laboratory diet and water Ad libitum exposed to a $12 \mathrm{~h} \mathrm{light/dark}$ cycle, and maintained at a laboratory temperature of $20^{\circ} \mathrm{C} \pm 2{ }^{\circ} \mathrm{C}$. The animals were quarantined for 7 days before beginning the experiments. All mice were handled in accordance with the standard guide for the care and use of laboratory animals and according to the guidelines laid by the Ethics committee of Aljouf University.

\subsection{Chemicals}

Cadmium in the form of $\mathrm{CdCl}_{2}$ was purchased from Sigma-Aldrich (St. Louis, MO, USA). Extra virgin olive oil (EVOO) was purchased from the local market in Sakaka city, Aljouf, KSA. Urea and creatinine kits were purchased from Biovision, USA. The other chemicals were purchased from Sigma (St. Louis, MO, USA).

\subsection{Experimental Design}

Forty mice with average weight of $20-30 \mathrm{~g}$ at the start of study were used in this experiment. The study was conducted in the Department of Pathology, College of Medicine, Aljouf University. Mice were randomly divided into four groups with 10 rats in each group.

Group 1: Animals were given distilled water orally at a daily dose of $2 \mathrm{~mL} / \mathrm{kg}$ body weight for 28 days, and served as the control group.

Group 2: Animals were given extra virgin olive oil orally at a daily dose of 2 $\mathrm{mL} / \mathrm{kg}$ body weight for 28 days [33].

Group 3: Animals were given $1.8 \mathrm{mg} \mathrm{CdCl}_{2} / \mathrm{kg}$ of body weight once a day 
(corresponding to $1 / 50 \mathrm{LD} 50$ ), dissolved in saline for a period of 28 days. The average oral lethal dose (LD50) value for $\mathrm{CdCl}_{2}$ in mice has been reported as 88 $\mathrm{mg} \mathrm{Cd} / \mathrm{kg}$ of body weight [34].

Group 4: Animals were given $\mathrm{CdCl}_{2}$ orally at a daily dose of $1.8 \mathrm{mg} \mathrm{CdCl} / 2 \mathrm{~kg}$ b.w/day and extra virgin olive oil at a daily dose of $2 \mathrm{~mL} / \mathrm{kg}$ body weight for 28 days.

\subsection{Sample Preparation}

Mice were fasted for 12 hours overnight at the end of the study period, and all the mice were sacrificed by cervical dislocation under the effect of anaesthesia of diethyl ether. The samples of blood were gathered from the mice and stored until biochemical analysis at $-70^{\circ} \mathrm{C}$. Ice cold saline buffer $(20 \mathrm{mM}$ Tris- $\mathrm{HCl}, 0.14$ $\mathrm{M} \mathrm{NaCl}$ buffer, $\mathrm{pH}$ 7.4) was used to rinse the kidney after its removal and weighing, and then a Potter Elvehjem homogenizer was used to homogenize it in the same minced solution. Lipid peroxidation assay was done immediately using the homogenate tissue, and homogenate aliquots were kept for further biochemical analysis.

\subsection{Biochemical Assays}

\subsubsection{Blood Creatinine and Urea Levels Estimation}

Trinder (1969) [35] method was used for assaying creatinine and urea levels utilizing the commercial diagnostic kits.

\subsubsection{Measurement of Renal Oxidative Markers}

The method of Aebi (1984) [36] was used to determine the renal catalase (CAT) activity in tissue homogenates. Renal homogenate activity of superoxide dismutase (SOD) was estimated according to Spitz and Oberley (2001) [37] technique. Renal level of Glutathione peroxidase (GPx) was estimated according to Lawrence and Burk (1976] [38] technique. According to the method of Ohkawa et al. (1979) [39] and Yagi $(1984,1976)$ [40] [41], thiobarbituric acid reactive substances (TBARS) measurement was used to estimate the lipid peroxidation and they was expressed in terms of malondialdehyde content.

\subsection{Histopathological Examination}

Mice kidneys were immediately immersed in $10 \%$ neutral buffered formalin solution and kept for 24 hours followed by $70 \%$ ethanol wash. Then tissue pieces were dehydrated by using ascending grades of alcohol and finally paraffin embedding was done. Sectioning was done using a rotary ultra-microtome, and sections were dried overnight. Finally, sections were stained with haematoxylin and eosin (H \& E) dyes and slides were observed under a light microscope. All histological slides were analysed by Leica micro imaging systems DMD 4000, USA.

\subsection{Statistical Analysis}

The collected data from the experiment were presented as mean \pm SD value. The 
table or figure legends have been used to state the number of animals per each group. The mean differences between the studied groups for each parameter were separately analysed using one way analysis of variance (ANOVA) followed by Student-Newman-Keuls test and this is after ascertaining the homogeneity of variance between treatment groups by Bartlett's test. Values of $p \leq 0.05$ were considered of statistical significance.

\section{Results}

\subsection{Effect of Cadmium (Cd), Extra Virgin Olive Oil (EV00) on Body and Kidney Weights}

Table 1 depicts that after 4 weeks breeding of the four groups with matched initial body weight, both final and relative body weights (RBW) were significantly decreased in G3 (the group administered Cd) compared to G1and G2 (control group and group given Extra virgin olive oil, respectively), ( $p \leq 0.05)$. After administration of the protective agents with $\mathrm{Cd}$ in $\mathrm{G} 4$ (Cd + Extra virgin olive oil), both final and RBW significantly increased compared to G3. Kidney weight and relative kidney weight (RKW) were significantly decreased in G3 compared to G1 and G2 ( $\mathrm{p} \leq 0.05)$. The protective agents significantly increased kidney weight and RKW in G4 compared to G3 ( $\mathrm{p} \leq 0.05)$ (Table 1).

\subsection{Effect of Cadmium (Cd), Extra Virgin Olive Oil (EVO0) on Renal Function Tests}

Table 2 showed that blood urea and serum creatinine levels have significantly increased in G3 compared to G1 and G2, ( $\mathrm{p} \leq 0.05)$. After administration of EVOO with $\mathrm{Cd}$ in group 4 , the levels of those markers significantly improved compared to Cd group (G3) $(\mathrm{p} \leq 0.05)$.

\subsection{Effect of Cadmium (Cd), Extra Virgin Olive Oil (EV00) on Kidney Oxidative Markers}

Table 3 showed that the antioxidant markers (e.g. CAT, SOD and GPx) levels

Table 1. Effects of cadmium (Cd), extra-virgin olive oil (EVOO) and their combination, on body weight gain, kidney weights of mice groups, after four weeks of treatment.

\begin{tabular}{ccccc}
\hline Parameters & G1 (Control) & G2 (EVOO) & G3 (Cd) & G4 (Cd + EVOO) \\
\hline IBW $(\mathrm{g})$ & $27.33 \pm 3.20$ & $27.66 \pm 3.14$ & $27.50 \pm 3.45$ & $28.00 \pm 2.76$ \\
FBW $(\mathrm{g})$ & $32.16 \pm 1.17$ & $32.00 \pm 1.41$ & $25.66 \pm 1.86^{\mathrm{ab}}$ & $32.00 \pm 1.67^{\mathrm{c}}$ \\
RBW & $118.62 \pm 9.74$ & $116.67 \pm 11.69$ & $94.02 \pm 7.83^{\mathrm{ab}}$ & $114.91 \pm 9.01^{\mathrm{c}}$ \\
KW & $2.25 \pm 0.19$ & $2.28 \pm 0.15$ & $1.36 \pm 0.18^{\mathrm{ab}}$ & $2.08 \pm 0.12^{\mathrm{c}}$ \\
RKW & $6.99 \pm 0.54$ & $7.14 \pm 0.50$ & $5.37 \pm 1.01^{\mathrm{ab}}$ & $6.53 \pm 0.63^{\mathrm{c}}$ \\
\hline
\end{tabular}

Data are mean \pm SD. G1: control; G2: EVOO; G3: Cd; G4: Cd + EVOO. IBW: Initial body weight; FBW: Final body weight; RBW: Relative body weight; RKW: Relative kidney weight. Relative body weight $=($ Final body weight/Initial body weight $) \times 100$. Relative kidney weight $=($ kidney weight $/$ Final body weight $) \times 100$. a. compared to the control (G1) group; b. compared to EVOO (G2) group; c. compared to Cd (G3) group-significant at $\mathrm{p} \leq 0.05$. 
Table 2. Effects of cadmium (Cd), extra virgin olive oil (EVOO) and their combination, on kidney functions after four weeks of treatment.

\begin{tabular}{ccccc}
\hline Parameters & G1 (Control) & G2 (EVOO) & G3 $(\mathrm{Cd})$ & G4 (Cd + EVOO) \\
\hline Bl Urea $(\mathrm{mg} / \mathrm{dl})$ & $26.72 \pm 1.88$ & $27.90 \pm 0.84$ & $44.60 \pm 0.83^{\mathrm{ab}}$ & $30.73 \pm 0.78^{\mathrm{c}}$ \\
S. Creatinine $(\mathrm{mg} / \mathrm{dl})$ & $0.74 \pm 0.03$ & $0.74 \pm 0.03$ & $0.96 \pm 0.02^{\mathrm{ab}}$ & $0.79 \pm 0.03^{\mathrm{c}}$ \\
\hline
\end{tabular}

Data are mean \pm SD. G1: control; G2: EVOO; G3: Cd; G4: Cd + EVOO. a. compared to the control (G1) group; b. compared to EVOO (G2) group; c. compared to Cd (G3) group-significant at $\mathrm{p} \leq 0.05$.

Table 3. Effects of cadmium (Cd), extra virgin olive oil (EVOO) and their combination, on oxidative stress markers in the kidneys of mice groups, after four weeks of treatment.

\begin{tabular}{ccccc}
\hline Parameters & G1 (Control) & G2(EVOO) & G3 (Cd) & G4 (Cd + EVOO) \\
\hline CAT & $290.83 \pm 7.78$ & $290.33 \pm 12.80$ & $205.00 \pm 11.17^{\mathrm{ab}}$ & $259.66 \pm 24.40^{\mathrm{abc}}$ \\
SOD & $45.50 \pm 2.94$ & $44.16 \pm 2.14$ & $34.00 \pm 2.76^{\mathrm{ab}}$ & $40.66 \pm 1.96^{\mathrm{abc}}$ \\
GPx & $2.48 \pm 0.22$ & $2.46 \pm 0.24$ & $1.35 \pm 0.10^{\mathrm{ab}}$ & $2.05 \pm 0.23^{\mathrm{abc}}$ \\
MDA & $23.83 \pm 1.94$ & $23.33 \pm 2.16$ & $43.66 \pm 3.20^{\mathrm{ab}}$ & $30.16 \pm 2.32^{\mathrm{abc}}$ \\
\hline
\end{tabular}

Data are mean \pm SD. G1: control; G2: EVOO; G3: Cd; G4: Cd + EVOO. CAT: Catalase; SOD: Superoxide dismutase; GPx: Glutathione peroxidase; MDA: Malondialdehyde. a. compared to the control (G1) group; b. compared to EVOO (G2) group; c. compared to Cd (G3) group-significant at $\mathrm{p} \leq 0.05$.

have significantly decreased in G3 compared to G1 and G2, while MDA has significantly increased compared to those groups $(\mathrm{p} \leq 0.05)$. After administration of EVOO with Cd in group 4, the levels of those markers significantly improved compared to Cd group (G3) ( $\mathrm{p} \leq 0.05)$, however they do not reach the normal levels of the control groups (G1 and G2).

\subsection{Histopathological Findings}

Histopathological examination of the renal tissue from control group (Figure 1) and the olive oil group (Figure 2) showed normal renal architecture whereas Cadmium group showed severe congestion of the renal blood vessels and severe damage of glomeruli, inflammatory cell infiltrate, and widening of glomerular space (Figure 3(a) and Figure 3(b)). EVOO + Cd group depicted nearly normal renal architecture with little inflammatory cell infiltration (Figure 4).

\section{Discussion}

Cadmium (Cd) is one of the common toxic agents that belongs to the heavy metal group. In the humans body, respiratory tract irritation and pulmonary oedema might occur after inhalation of $\mathrm{Cd}$, while bone fractures, renal dysfunction, osteoporosis and anaemia often occurred after chronic Cd exposure [42].

The molecular mechanism accountable for the toxic effects of $\mathrm{Cd}$ has not so far been entirely elucidated but it has been proposed that the formation of reactive oxygen species (ROS) leads to oxidative damage in various tissues with consequent loss of function of the membrane [43]. 


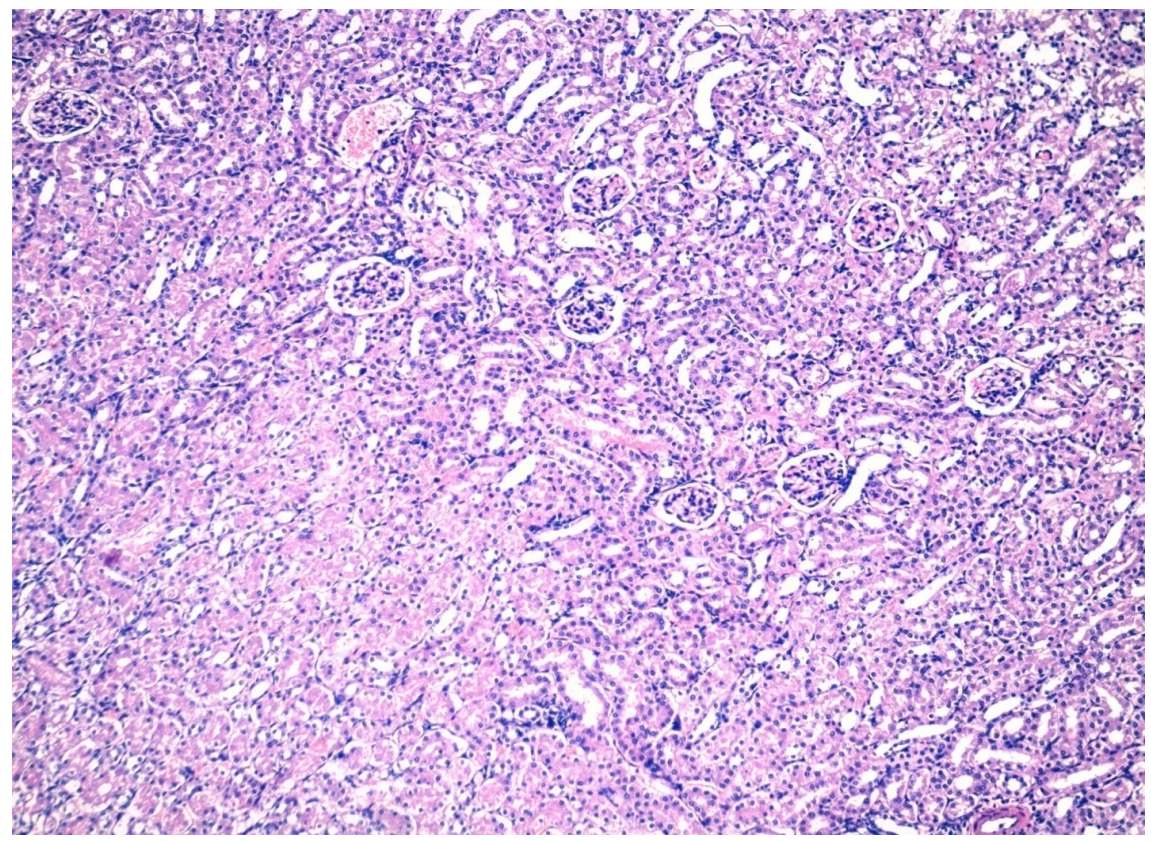

Figure 1. Photomicrograph of renal tissue from the Group-I (control group) shows normal renal architecture $(\mathrm{H} \& \mathrm{E} \times 100)$.

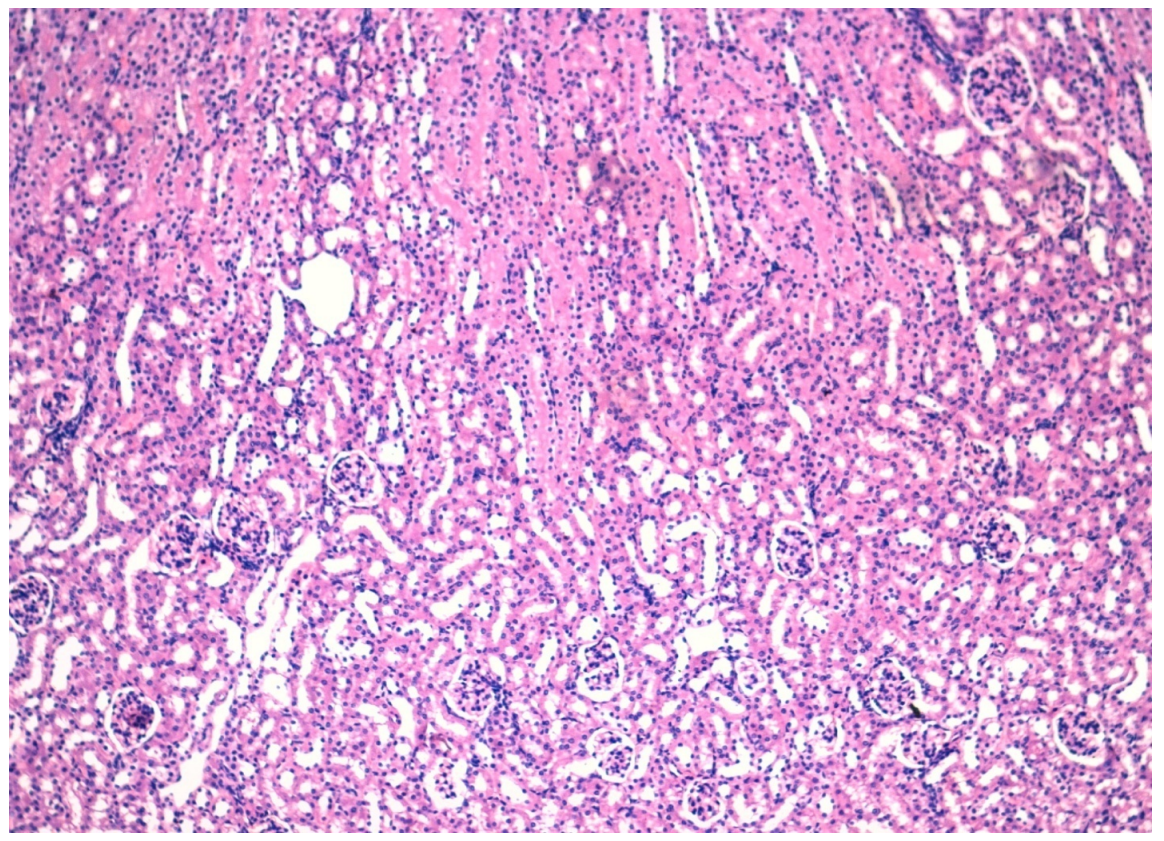

Figure 2. Photomicrograph of renal tissue from the Group-II (olive oil group) shows normal renal architecture $(\mathrm{H} \& \mathrm{E} \times 100)$.

Long-term exposure to Cd causes derangement of antioxidant system with inhibition of antioxidant enzymes. Many studies proved that the oxidative stress was the major instigator of the toxic effects of cadmium in the kidneys [44]. In this study, we tested the toxic effects of cadmium on kidney. Furthermore, we evaluated the role of EVOO as an antioxidant to recover the tissues from the toxic effects of cadmium. 


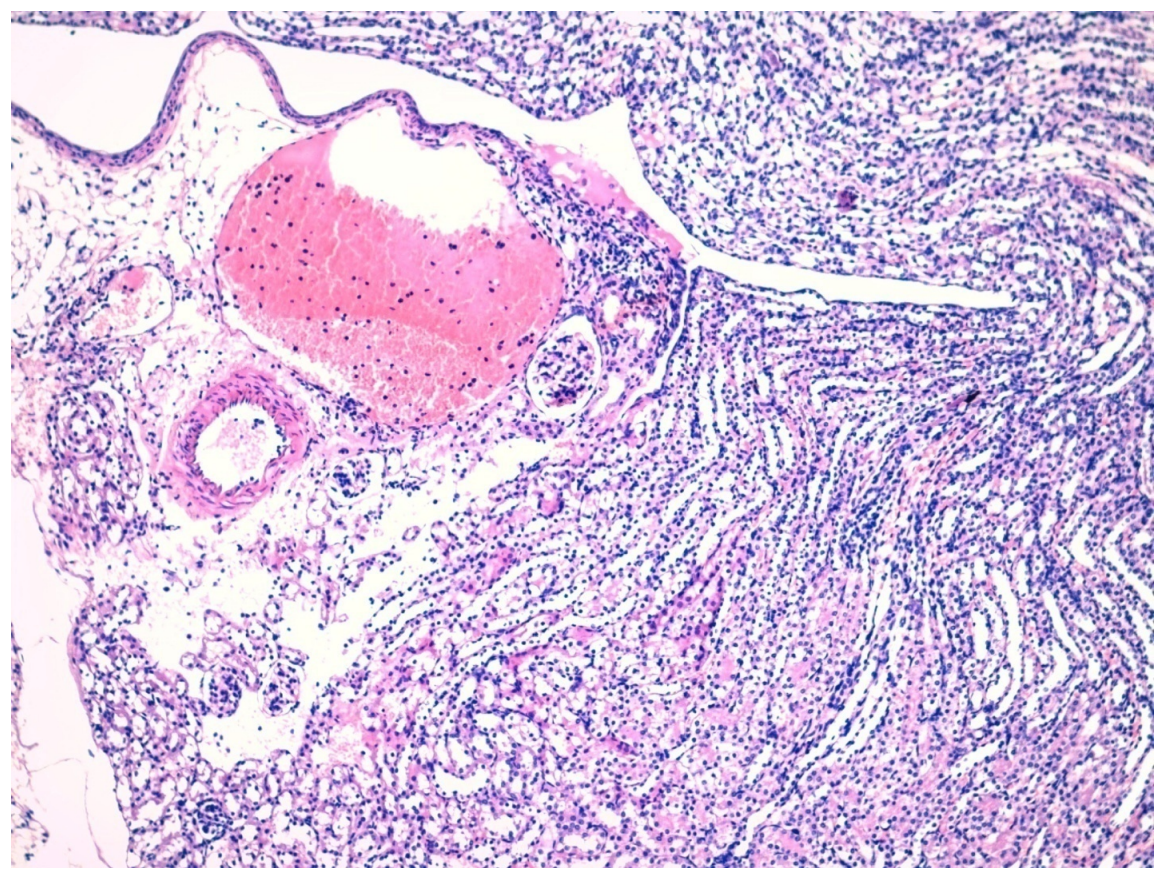

(a)

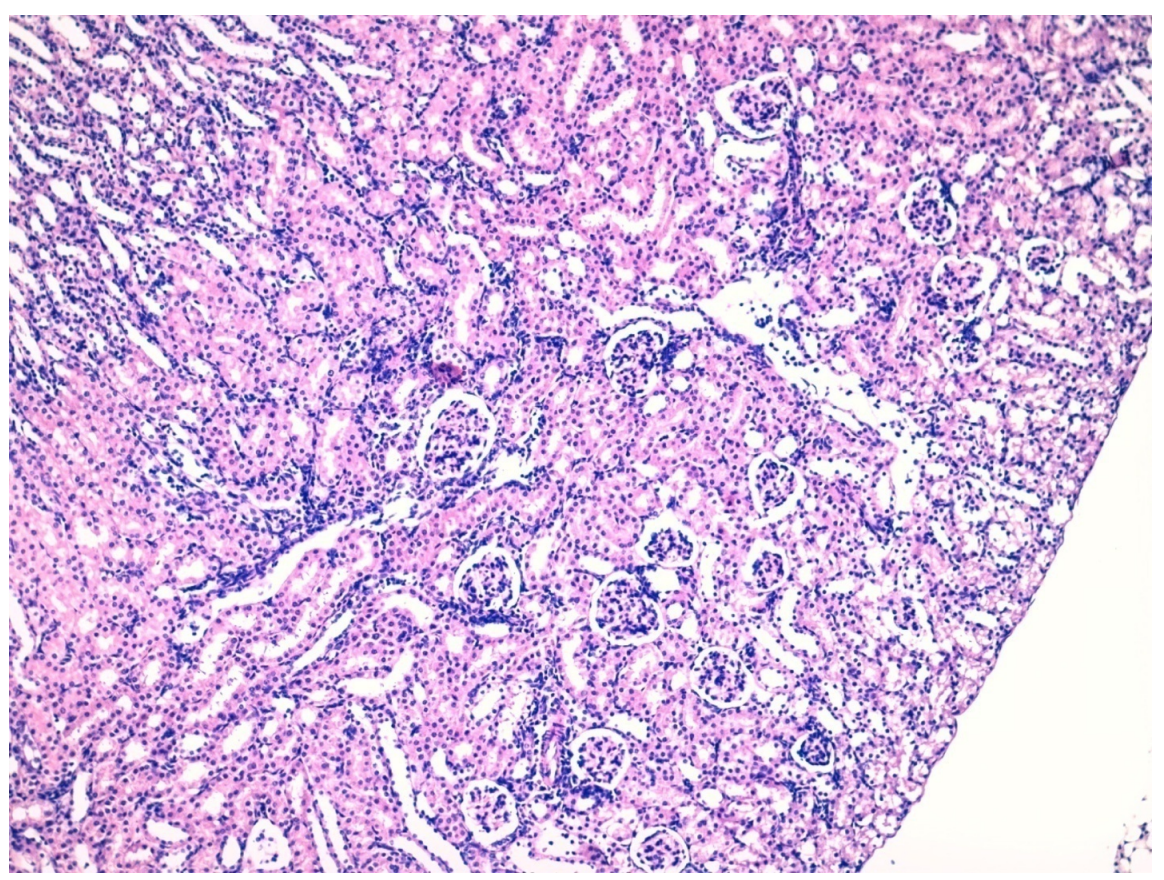

(b)

Figure 3. (a) Photomicrograph of renal tissue from the Group-III (cadmium group) shows severe congestion of blood vessels along with edema and inflammatory cell infiltrate. The surrounding glomeruli and tubules are damaged (H \& E $\times 100)$; (b) Photomicrograph of renal tissue from the Group-III (Cadmium group) shows mononuclear inflammatory cell infiltration, severe damage to some of the glomeruli and widening of the Bowman's space $(\mathrm{H} \& \mathrm{E} \times 100)$.

By the end of our experiment, the body weight of the animals was determined in grams and it was found that the control group mice (G1) gained some body 


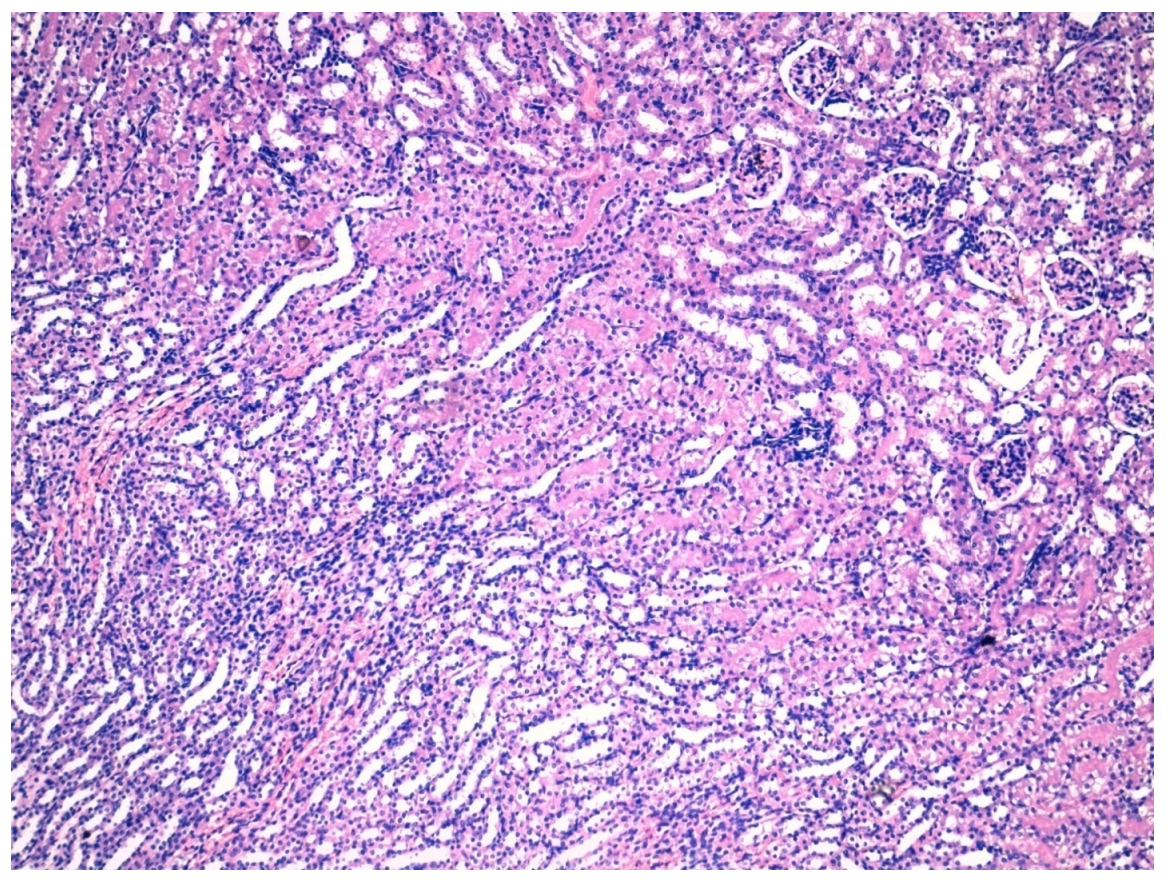

Figure 4. Photomicrograph of renal tissue from the Group-IV (Cd + EVOO group) shows near normal renal architecture with few inflammatory cells $(\mathrm{H} \& \mathrm{E} \times 100)$.

weight during the experiment referenced to their weight at the start of the experiment. The cadmium alone (G3) group caused the biggest weight loss. Adding EVOO significantly reduced the loss of body weight caused by cadmium. These finding are in agreement with Ibraheem et al. (2016) [45] who found that Cd administration to a group of mice caused weight loss. Cadmium binds to sulfhydryl groups and leads to structural distortion of proteins [46]. The ability of EVOO to reduce cadmium effect on body weight is reasonable since EVOO contains many components that have been shown to be fundamental for more than hundreds of the enzymatic reactions and also fundamental for the function and structure of a great proportion of macromolecules [47] [48].

Creatinine is produced in the kidney, liver and pancreas where it is phosphorylated and transported to the brain and muscle tissue [49]. This study demonstrated that serum creatinine and urea were significantly increased in Cd treated group than in control group. These findings are similar to the findings of many researchers [50] [51] [52] whose results depicted the effect of Cd intoxication on serum urea and creatinine levels, where $\mathrm{Cd}$ administration caused a significant serum elevation of the levels of the creatinine and urea when compared with the control ( $\mathrm{p} \leq 0.05$ ). Co-administration with EVOO restores the renal functions to near normal range. This might be caused by the antioxidant effect of EVOO on the Cd toxicity.

To be used as an indicator of lipid peroxidation, the tissue level of MDA was measured in the current study. The kidney tissue level of MDA was significantly elevated in the mice treated and intoxicated with $\mathrm{Cd}$ alone. The data available from our study depicted that oxidative stress has an essential role that explained 
the toxicity and the damage that occur in the kidney tissue. Our findings are in agreement with the previous researches that reported the important role of oxidative stress in Cd toxicity [53] [54] [55]. The increased MDA levels in renal tissue is an indication of the increased levels of lipid peroxides in kidney tissue, causing increased consumption of functional thiol (-SH) groups and its depletion in many antioxidant enzymes, as we noticed in the decreased tissue levels of GPx, SOD and CAT enzymes in the current study. This is in agreement with Liu et al. (2008) [56] who stated that DNA damage occurred in Cd induced toxicity as a result from the increased and accumulation of ROS which generate lipid peroxidation. This is in contrast with finding of Thijssen et al. (2007) [57] who stated that following oral administration of $\mathrm{Cd}$ in chronic studies and after long period of $\mathrm{Cd}$ exposure, these is lack of ROS production in the tissues.

Previous studies [58] [59] [60] [61] depict that Cd toxicity is mediated through the reactive oxygen species (ROS), either in intact mice through all exposure routes or, in an assortment of cell culture systems. The mechanism of membranes, proteins and DNA damage that occur in Cd toxicity results from the oxidative stress that encompassed of the imbalance between production and elimination of ROS in the components of tissues and cells [53]. The lipid peroxidation of the membrane-bound polyunsaturated fatty acids in Cd induced toxicity was initiated by the production of ROS, leading to ailment of the functional and structural integrity of the membrane, which is the outcome of an interaction between unsaturated fatty acids and free radicals of diverse origins that are model in the lipids of membrane. Cadmium toxicity induced the polyunsaturated fatty acids degradation in the cell membrane by the generation of ROS, which results in the impairment of membranes and the generation of thiobarbituric acid reactive species, MDA , used as lipid peroxidation indicators with the conjugated dienes [62] [63].

Liu et al. (2008) [56] proposed that the glutathione depletion and sulfhydryl group binding properties of cadmium increased the production of ROS and suggested these to be the mechanism responsible for Cd toxicity. The co-administration of $\mathrm{EVOO}$ with $\mathrm{Cd}$ ameliorated the toxic effect of $\mathrm{Cd}$ and restored the antioxidant enzyme levels to their normal state with reduced MDA level.

Administration of cadmium caused severe damage to the renal glomeruli manifesting with damage to the glomerular epithelium and tubules, inflammatory cell infiltrate and severe congestion of the renal blood vessels (Figure 3(a) and Figure 3(b)). The glomeruli and proximal tubules in the kidney, both of them showed swelling; hyperplasia of the tubules, widening of Bowman's space, interstitial necrosis and fibrosis, atrophy of glomeruli were also observed. Our results were in agreement with those of E. Mohammad [31]; Damek-Poprawa (2003) [62] and Sawicka-Kapusta; Järup (2002) [63] and Ohta (2000) [64].

The administration of olive oil with Cadmium prevented the damage in the kidneys as evidenced by changes in only few glomerular structures and little inflammatory cell infiltrate (Figure 4). These changes were observed by Mohammad (2014) 
[31] who attributed these to the increased activity of the anti-oxidant enzymes and reduced MDA levels in the renal tissues. Olive oil inhibits the lipid and protein peroxidation and improves the antioxidant mechanism because of their high phenolic compounds as has been proved previously [65] [66] [67]. Besides phenolic compounds, other compounds which have beneficial effects include monounsaturated fatty acids, oleic acid and tocopherols [68] [69].

Nakbi et al. (2010) [47] reported that the nutrigenomic effects of the polyphenol-rich watery (hydrophilic) components on the body's own antioxidant network are mainly associated with the protective effects of olive oil against oxidative damage. The polyphenol-rich hydrophilic fraction of olive oil appears to be effective in decreasing oxidative stress induced by toxins.

\section{Conclusion}

The kidney is considered as one of the major target organs affected by Cadmium toxicity. Cadmium can accumulate in the kidneys and cause severe tissue damage, as was observed from the results in our study. Our results demonstrated that Cadmium increases the oxidative stress by depleting CAT and inhibiting the activities of antioxidant enzymes. The treatment with EVOO significantly protected the Cadmium-induced oxidative stress. The study suggests that EVOO can be used as a cost effective safe anti-oxidative agent in the prevention of Cadmium toxicity.

\section{Acknowledgements}

The authors are greatly thankful to the Deanship of Scientific Research of Aljouf University whose financial support made this study possible. The team is extremely thankful to the Pathology and Biochemistry departments for facilitating the working of the project.

\section{Funding Statement}

This work was supported by the Deanship of Scientific Research, Aljouf University, Grant No. 377/37.

\section{Conflict of Interest Statement}

The authors declare that there are no conflicts of interest.

\section{References}

[1] Bernhoft, R.A. (2013) Cadmium Toxicity and Treatment. The Scientific World Journal, 2013, Article ID: 394652. https://doi.org/10.1155/2013/394652

[2] Satarug, S., Garrett, S.H., Sens, M.A. and Sens, D.A. (2011) Cadmium, Environmental Exposure, and Health Outcomes. Ciencia \& Saude Coletiva, 16, 2587-2602. https://doi.org/10.1590/S1413-81232011000500029

[3] Paschal, D., Burt, V., Caudill, S., Gunter, E., Pirkle, J., Sampson, E., et al. (2000) Exposure of the US Population Aged 6 Years and Older to Cadmium: 1988-1994. Archives of Environmental Contamination and Toxicology, 38, 377-383. https://doi.org/10.1007/s002449910050 
[4] Honda, R., Swaddiwudhipong, W., Nishijo, M., Mahasakpan, P., Teeyakasem, W., Ruangyuttikarn, W., et al. (2010) Cadmium Induced Renal Dysfunction among Residents of Rice Farming Area Downstream from a Zinc-Mineralized Belt in Thailand. Toxicology Letters, 198, 26-32.

https://doi.org/10.1016/j.toxlet.2010.04.023

[5] Stellman, S.D. (1980) IARC Monographs on the Evaluation of the Carcinogenic Risk of Chemicals to Humans. Saccharin, a Report by Dr. Morris F. Cranmer: Vol. 22, Some Non-Nutritive Sweetening Agents. Pathotox Publishers, Inc., Chicago, 586 p.

[6] Godt, J., Scheidig, F., Grosse-Siestrup, C., Esche, V., Brandenburg, P., Reich, A., et al. (2006) The Toxicity of Cadmium and Resulting Hazards for Human Health. Journal of Occupational Medicine and Toxicology, 1, 22.

https://doi.org/10.1186/1745-6673-1-22

[7] Erfurt, C., Roussa, E. and Thévenod, F. (2003) Apoptosis by Cd 2+ or CdMT in Proximal Tubule Cells: Different Uptake Routes and Permissive Role of Endo/Lysosomal CdMT Uptake. American Journal of Physiology-Cell Physiology, 285, C1367-C1376. https://doi.org/10.1152/ajpcell.00217.2003

[8] Gobe, G. and Crane, D. (2010) Mitochondria, Reactive Oxygen Species and Cadmium Toxicity in the Kidney. Toxicology Letters, 198, 49-55.

https://doi.org/10.1016/j.toxlet.2010.04.013

[9] Dorian, C., Gattone, V.H. and Klaassen, C.D. (1992) Accumulation and Degradation of the Protein Moiety of Cadmium-Metallothionein (CdMT) in the Mouse Kidney. Toxicology and Applied Pharmacology, 117, 242-248.

https://doi.org/10.1016/0041-008X(92)90243-L

[10] Vesey, D.A. (2010) Transport Pathways for Cadmium in the Intestine and Kidney Proximal Tubule: Focus on the Interaction with Essential Metals. Toxicology Letters, 198, 13-19. https://doi.org/10.1016/j.toxlet.2010.05.004

[11] Gunshin, H., Mackenzie, B., Berger, U.V., Gunshin, Y., Romero, M.F., Boron, W.F., et al. (1997) Cloning and Characterization of a Mammalian Proton-Coupled Metal-Ion Transporter. Nature, 388, 482-488. https://doi.org/10.1038/41343

[12] Olivi, L., Sisk, J. and Bressler, J. (2001) Involvement of DMT1 in Uptake of Cd in MDCK Cells: Role of Protein Kinase C. American Journal of Physiology-Cell Physiology, 281, C793-C800. https://doi.org/10.1152/ajpcell.2001.281.3.C793

[13] Zalups, R.K. and Ahmad, S. (2003) Molecular Handling of Cadmium in Transporting Epithelia. Toxicology and Applied Pharmacology, 186, 163-188. https://doi.org/10.1016/S0041-008X(02)00021-2

[14] Himeno, S., Yanagiya, T. and Fujishiro, H. (2009) The Role of Zinc Transporters in Cadmium and Manganese Transport in Mammalian Cells. Biochimie, 91, 1218-1222. https://doi.org/10.1016/j.biochi.2009.04.002

[15] Wang, L., Li, J., Li, J. and Liu, Z. (2010) Effects of Lead and/or Cadmium on the Oxidative Damage of Rat Kidney Cortex Mitochondria. Biological Trace Element Research, 137, 69-78. https://doi.org/10.1007/s12011-009-8560-1

[16] Thévenod, F. (2003) Nephrotoxicity and the Proximal Tubule. Nephron Physiology, 93, 87-93. https://doi.org/10.1159/000070241

[17] Bridges, C.C. and Zalups, R.K. (2005) Molecular and Ionic Mimicry and the Transport of Toxic Metals. Toxicology and Applied Pharmacology, 204, 274-308. https://doi.org/10.1016/j.taap.2004.09.007

[18] Jiang, Y., Lee, A., Chen, J., Cadene, M., Chait, B.T. and MacKinnon, R. (2002) Crystal Structure and Mechanism of a Calcium-Gated Potassium Channel. Nature, 417, 515-522. https://doi.org/10.1038/417515a 
[19] Gennari, A., Cortese, E., Boveri, M., Casado, J. and Prieto, P. (2003) Sensitive Endpoints for Evaluating Cadmium-Induced Acute Toxicity in LLC-PK1 Cells. Toxicology, 183, 211-220. https://doi.org/10.1016/S0300-483X(02)00546-2

[20] Lee, S.-H., Ahsan, N., Lee, K.-W., Kim, D.-H., Lee, D.-G., Kwak, S.-S., et al. (2007) Simultaneous Overexpression of Both CuZn Superoxide Dismutase and Ascorbate Peroxidase in Transgenic Tall Fescue Plants Confers Increased Tolerance to a Wide Range of Abiotic Stresses. Journal of Plant Physiology, 164, 1626-1638.

https://doi.org/10.1016/j.jplph.2007.01.003

[21] Chen, J. and Shaikh, Z.A. (2009) Activation of Nrf2 by Cadmium and Its Role in Protection against Cadmium-Induced Apoptosis in Rat Kidney Cells. Toxicology and Applied Pharmacology, 241, 81-89. https://doi.org/10.1016/j.taap.2009.07.038

[22] Quamme, G.A. (1992) Free Cadmium Activity in Renal Epithelial Cells Is Enhanced by Mg2+ Depletion. Kidney International, 41, 1237-1244.

https://doi.org/10.1038/ki.1992.185

[23] Goyer, R.A., Miller, C.R., Zhu, S.-Y. and Victery, W. (1989) Non-MetallothioneinBound Cadmium in the Pathogenesis of Cadmium Nephrotoxicity in the Rat. Toxicology and Applied Pharmacology, 101, 232-244. https://doi.org/10.1016/0041-008X(89)90272-X

[24] Foulkes, E. and Blanck, S. (1990) Acute Cadmium Uptake by Rabbit Kidneys: Mechanism and Effects. Toxicology and Applied Pharmacology, 102, 464-473. https://doi.org/10.1016/0041-008X(90)90042-S

[25] Waterman, E. and Lockwood, B. (2007) Active Components and Clinical Applications of Olive Oil. Alternative Medicine Review, 12, 331-343.

[26] Benavente-Garcia, O., Castillo, J., Lorente, J., Ortuno, A. and Del Rio, J. (2000) Antioxidant Activity of Phenolics Extracted from Olea europaea L. Leaves. Food Chemistry, 68, 457-462. https://doi.org/10.1016/S0308-8146(99)00221-6

[27] Bitler, C.M., Viale, T.M., Damaj, B. and Crea, R. (2005) Hydrolyzed Olive Vegetation Water in Mice Has Anti-Inflammatory Activity. The Journal of Nutrition, 135, 1475-1479.

[28] López-Miranda, J., Pérez-Jiménez, F., Ros, E., De Caterina, R., Badimón, L., Covas, M., et al. (2010) Olive Oil and Health: Summary of the II International Conference on Olive Oil and Health Consensus Report, Jaén and Córdoba (Spain) 2008. Nutrition, Metabolism and Cardiovascular Diseases, 20, 284-294. https://doi.org/10.1016/j.numecd.2009.12.007

[29] Masella, R., Giovannini, C., Varì, R., Di Benedetto, R., Coni, E., Volpe, R., et al. (2001) Effects of Dietary Virgin Olive Oil Phenols on Low Density Lipoprotein Oxidation in Hyperlipidemic Patients. Lipids, 36, 1195-1202.

https://doi.org/10.1007/s11745-001-0832-3

[30] Coni, E., Di Benedetto, R., Di Pasquale, M., Masella, R., Modesti, D., Mattei, R., et al. (2000) Protective Effect of Oleuropein, An Olive Oil Biophenol, on Low Density Lipoprotein Oxidizability in Rabbits. Lipids, 35, 45-54.

https://doi.org/10.1007/s11745-000-0493-2

[31] Mohammed, E., Hashem, K. and Rheim, M. (2014) Biochemical Study on the Impact of Nigella sativa and Virgin Olive Oils on Cadmium-Induced Nephrotoxicity and Neurotoxicity in Rats. Journal of Investigational Biochemistry, 3, 71-78. https://doi.org/10.5455/jib.20140716041908

[32] Amamou, F., Nemmiche, S., Kaouthar Meziane, R., Didi, A., Yazit, S.M. and Chabane-Sari, D. (2015) Protective Effect of Olive Oil and Colocynth Oil against Cadmium-Induced Oxidative Stress in the Liver of Wistar Rats. Food and Chemical 
Toxicology, 78, 177-184. https://doi.org/10.1016/j.fct.2015.01.001

[33] Ibrahim, M.A.B., Wani, F.A. and Rahiman, S. (2017) Hepatoprotective Effect of Olive Oil and Camel Milk on Acetaminophen-Induced Liver Toxicity in Mice. International Journal of Medical Science and Public Health, 6, 186-194. https://doi.org/10.5455/ijmsph.2017.07092016614

[34] Lehman, A.J. (1951) Chemicals in Foods: A Report to the Association of Food and Drug Officials on Current Developments. Part II. Pesticides. Section I. Introduction. Association of Food and Drug Officials of the United States-Quarterly Bulletin, 15, 122-123.

[35] Trinder, P. (1969) Determination of Glucose in Blood Using Glucose Oxidase with an Alternative Oxygen Acceptor. Annals of Clinical Biochemistry: An International Journal of Biochemistry in Medicine, 6, 24-27. https://doi.org/10.1177/000456326900600108

[36] Aebi, H. (1984) Catalase In Vitro. Methods in Enzymology, 105, 121-126. https://doi.org/10.1016/S0076-6879(84)05016-3

[37] Spitz, D.R. and Oberley, L.W. (2001) Measurement of MnSOD and CuZnSOD Activity in Mammalian Tissue Homogenates. Current Protocols in Toxicology, 7.5. 1-7.5.11.

[38] Lawrence, R.A. and Burk, R.F. (1976) Glutathione Peroxidase Activity in Selenium-Deficient Rat Liver. Biochemical and Biophysical Research Communications, 71, 952-958. https://doi.org/10.1016/0006-291X(76)90747-6

[39] Ohkawa, H., Ohishi, N. and Yagi, K. (1979) Assay for Lipid Peroxides in Animal Tissues by Thiobarbituric Acid Reaction. Analytical Biochemistry, 95, 351-358. https://doi.org/10.1016/0003-2697(79)90738-3

[40] Yagi, K. (1984) Assay for Blood Plasma or Serum. Methods in Enzymology, 105, 328-331. https://doi.org/10.1016/S0076-6879(84)05042-4

[41] Yagi, K. (1976) A Simple Fluorometric Assay for Lipoperoxide in Blood Plasma. Biochemical Medicine, 15, 212-216. https://doi.org/10.1016/0006-2944(76)90049-1

[42] Friberg, L., Elinder, C., Kjellstrom, T. and Nordberg, G. (1985) Cadmium and Health: A Toxicological and Epidemiological Appraisal Volume II: Effects and Response. CRC Press, Boca Raton.

[43] Sarkar, S., Yadav, P., Trivedi, R., Bansal, A. and Bhatnagar, D. (1995) Cadmium-Induced Lipid Peroxidation and the Status of the Antioxidant System in Rat Tissues. Journal of Trace Elements in Medicine and Biology, 9, 144-149. https://doi.org/10.1016/S0946-672X(11)80038-6

[44] Casalino, E., Calzaretti, G., Sblano, C. and Landriscina, C. (2002) Molecular Inhibitory Mechanisms of Antioxidant Enzymes in Rat Liver and Kidney by Cadmium. Toxicology, 179, 37-50. https://doi.org/10.1016/S0300-483X(02)00245-7

[45] Ibraheem, A.S., Seleem, A.A., El-Sayed, M.F. and Hamad, B.H. (2016) Single or Combined Cadmium and Aluminum Intoxication of Mice Liver and Kidney with Possible Effect of Zinc. The Journal of Basic \& Applied Zoology, 77, 91-101. https://doi.org/10.1016/j.jobaz.2016.12.004

[46] Valko, M., Morris, H. and Cronin, M. (2005) Metals, Toxicity and Oxidative Stress. Current Medicinal Chemistry, 12, 1161-1208. https://doi.org/10.2174/0929867053764635

[47] Nakbi, A., Tayeb, W., Grissa, A., Issaoui, M., Dabbou, S., Chargui, I., et al. (2010) Effects of Olive Oil and Its Fractions on Oxidative Stress and the Liver's Fatty Acid Composition in 2,4-Dichlorophenoxyacetic Acid-Treated Rats. Nutrition \& meta- 
bolism, 7, 80. https://doi.org/10.1186/1743-7075-7-80

[48] Kasdallah-Grissa, A., Nakbi, A., Koubaa, N., El-Fazaâ, S., Gharbi, N., Kamoun, A., et al. (2008) Dietary Virgin Olive Oil Protects against Lipid Peroxidation and Improves Antioxidant Status in the Liver of Rats Chronically Exposed to Ethanol. $\mathrm{Nu}$ trition Research, 28, 472-479. https://doi.org/10.1016/j.nutres.2008.03.014

[49] Harita, N., Hayashi, T., Sato, K.K., Nakamura, Y., Yoneda, T., Endo, G., et al. (2009) Lower Serum Creatinine Is a New Risk Factor of Type 2 Diabetes. Diabetes Care, 32, 424-426. https://doi.org/10.2337/dc08-1265

[50] Akinyemi, A.J., Onyebueke, N., Faboya, O.A., Onikanni, S.A., Fadaka, A. and Olayide, I. (2017) Curcumin Inhibits Adenosine Deaminase and Arginase Activities in Cadmium-Induced Renal Toxicity in Rat Kidney. Journal of Food and Drug Analysis, 25, 438-46. https://doi.org/10.1016/j.jfda.2016.06.004

[51] Yadav, N. and Khandelwal, S. (2006) Effect of Picroliv on Cadmium-Induced Hepatic and Renal Damage in the Rat. Human \& Experimental Toxicology, 25, 581-91. https://doi.org/10.1177/096032706072455

[52] Lee, Y.K., Park, E.Y., Kim, S., Son, J.Y., Kim, T.H., Kang, W.G., et al. (2014) Evaluation of Cadmium-Induced Nephrotoxicity Using Urinary Metabolomic Profiles in Sprague-Dawley Male Rats. Journal of Toxicology and Environmental Health, Part $A, 77,1384-1398$. https://doi.org/10.1080/15287394.2014.951755

[53] Yang, H. and Shu, Y. (2015) Cadmium Transporters in the Kidney and Cadmium-Induced Nephrotoxicity. International Journal of Molecular Sciences, 16, 1484-1494. https://doi.org/10.3390/ijms16011484

[54] Sompamit, K., Kukongviriyapan, U., Donpunha, W., Nakmareong, S. and Kukongviriyapan, V. (2010) Reversal of Cadmium-Induced Vascular Dysfunction and Oxidative Stress by Meso-2,3-Dimercaptosuccinic Acid in Mice. Toxicology Letters, 198, 77-82. https://doi.org/10.1016/j.toxlet.2010.04.007

[55] El-Boshy, M.E., Risha, E.F., Abdelhamid, F.M., Mubarak, M.S. and Hadda, T.B. (2015) Protective Effects of Selenium against Cadmium Induced Hematological Disturbances, Immunosuppressive, Oxidative Stress and Hepatorenal Damage in Rats. Journal of Trace Elements in Medicine and Biology, 29, 104-110. https://doi.org/10.1016/j.jtemb.2014.05.009

[56] Liu, J., Qian, S.Y., Guo, Q., Jiang, J., Waalkes, M.P., Mason, R.P., et al. (2008) Cadmium Generates Reactive Oxygen- and Carbon-Centered Radical Species in Rats: Insights from In Vivo Spin-Trapping Studies. Free Radical Biology and Medicine, 45, 475-481. https://doi.org/10.1016/j.freeradbiomed.2008.04.041

[57] Thijssen, S., Cuypers, A., Maringwa, J., Smeets, K., Horemans, N., Lambrichts, I., et al. (2007) Low Cadmium Exposure Triggers a Biphasic Oxidative Stress Response in Mice Kidneys. Toxicology, 236, 29-41. https://doi.org/10.1016/j.tox.2007.03.022

[58] He, X., Chen, M.G. and Ma, Q. (2008) Activation of Nrf2 in Defense against Cadmium-Induced Oxidative Stress. Chemical Research in Toxicology, 21, 1375-1383. https://doi.org/10.1021/tx800019a

[59] Amara, S., Abdelmelek, H., Garrel, C., Guiraud, P., Douki, T., Ravanat, J.-L., et al. (2008) Preventive Effect of Zinc against Cadmium-Induced Oxidative Stress in the Rat Testis. Journal of Reproduction and Development, 54, 129-134. https://doi.org/10.1262/jrd.18110

[60] Liu, F. and Jan, K.-Y. (2000) DNA Damage in Arsenite-And Cadmium-Treated Bovine Aortic Endothelial Cells. Free Radical Biology and Medicine, 28, 55-63. https://doi.org/10.1016/S0891-5849(99)00196-3

[61] Yamano, T., DeCicco, L.A. and Rikans, L.E. (2000) Attenuation of Cadmium-Induced 
Liver Injury in Senescent Male Fischer 344 Rats: Role of Kupffer Cells and Inflammatory Cytokines. Toxicology and Applied Pharmacology, 162, 68-75. https://doi.org/10.1006/taap.1999.8833

[62] Eşrefoğlu, M., Gül, M., Ateş, B. and Yilmaz, I. (2006) Ultrastructural Clues for the Protective Effect of Ascorbic Acid and N-Acetylcysteine against Oxidative Damage on Caerulein-Induced Pancreatitis. Pancreatology, 6, 477-85. https://doi.org/10.1159/000094665

[63] Ibrahim, M.A., et al. (2017) Protective Effect of Silymarin and Ascorbic Acid in Valproic Acid Induced Hepatic Toxicity in Male Albino Rats. Mansoura Journal of Forensic Medicine \& Clinical Toxicology, 25, 33-49.

[64] Ohta, H., Yamauchi, Y., Nakakita, M., Tanaka, H., Asami, S., Seki, Y., et al. (2000) Relationship between Renal Dysfunction and Bone Metabolism Disorder in Male Rats after Long-Term Oral Quantitative Cadmium Administration. Industrial Health, 38, 339-355. https://doi.org/10.2486/indhealth.38.339

[65] Ghorbel, I., Khemakhem, M., Boudawara, O., Marrekchi, R., Jamoussi, K., Amar, R.B., et al. (2015) Effects of Dietary Extra Virgin Olive Oil and Its Fractions on Antioxidant Status and DNA Damage in the Heart of Rats Co-Exposed to Aluminum and Acrylamide. Food \& Function, 6, 3098-3108.

https://doi.org/10.1039/C5FO00342C

[66] Bonilla, P.A., Murillo, R.J., González, B.J. and Sanz, P.B. (1996) Variations in Fatty Acids, Tocopherol and Other Quality Parameters of Virgin Olive Oil Subjected to Refining Process. Nutricion Hospitalaria, 12, 309-311.

[67] Covas, M.-I., Nyyssönen, K., Poulsen, H.E., Kaikkonen, J., Zunft, H.-J.F., Kiesewetter, H., et al. (2006) The Effect of Polyphenols in Olive Oil on Heart Disease Risk FactorsA Randomized Trial Olive Oil Polyphenols and Heart Disease Risk. Annals of Internal Medicine, 145, 333-341. https://doi.org/10.7326/0003-4819-145-5-200609050-00006

[68] Khalil, S., Awad, A. and Elewa, Y. (2013) Antidotal Impact of extra Virgin Olive Oil against Genotoxicity, Cytotoxicity and Immunotoxicity Induced by Hexavalent Chromium in Rat. International Journal of Veterinary Science and Medicine, 1, 65-73. https://doi.org/10.1016/j.ijvsm.2013.10.001

[69] Vinha, A.F., Ferreres, F., Silva, B.M., Valentao, P., Gonçalves, A., Pereira, J.A., et al. (2005) Phenolic Profiles of Portuguese Olive Fruits (Olea europaea L.): Influences of Cultivar and Geographical Origin. Food Chemistry, 89, 561-568.

https://doi.org/10.1016/j.foodchem.2004.03.012

\section{Abbreviations}

\section{Cadmium: Cd}

Extra virgin olive oil: EVOO

Catalase: CAT

Malondialdehyde: MDA

Superoxide dismutase: SOD

Glutathione peroxidase: GPx

Reactive oxygen species: ROS 